\title{
SOLID FOUNDATIONS? TOWARDS A HISTORICAL SOCIOLOGY OF PRISON BUILDING PROGRAMMES IN ENGLAND AND WALES, 1959-2015
}

\begin{abstract}
Between 1959 and 2015 the UK government embarked upon five major phases of prison building in England and Wales. Drawing upon detailed archival research this article offers a historical sociology of prison building programmes. It traces the evolution of prison building as a public policy concern and documents how this key site of penal-policymaking was interpreted, and contested by, policy actors who were themselves embedded within deep institutional structures of power and meaning. It argues that prison building has moved from the margins to the mainstream of penal policy, shaped by strongly held convictions about the liberal-democratic state, the competition for control of finite resources and the complex 'geography of administration' that underpins the British machinery of government.
\end{abstract}

Key Words: prison, penal policy, punishment, law and order politics

\section{Introduction}

In November 2015, the Chancellor of the Exchequer, George Osborne, and Justice Secretary, Michael Gove, announced plans for a major prison building programme in England and Wales. This $£ 1.3$ bn investment was lauded as a 'once in a generation' opportunity to modernise the prison estate, delivering nine purpose-built prisons and refurbishing 10,000 prison places by 2020 (Cabinet Office 2015). As the Prime Minister would later note, prison building was intended to provide the stimulus for 'the biggest shake up in the way our prisons are run since the Victorian times' (Prime Minister's Office 2016), however, progress quickly stalled as shortterm operational requirements collided with broader strategic aims. Addressing the Prison 
Governor's Association (PGA) in October 2017, the then Chief Executive of Her Majesty's Prison and Probation Service (HMPPS), Michael Spurr, revealed that following a rapid, and largely unexpected, summer increase in the prison population, 'I anticipate that we won't close any prisons this parliament' (The Guardian 2017). This development cast doubt over a central revenue stream underpinning the prison reform programme, leading one former Home Office finance director to describe existing commitments as 'unaffordable' (Le Vay 2017).

These events have reopened longstanding debates over the cost-effectiveness of imprisonment and the appropriate policy response to a growing, and increasingly complex prison population (Hough et al 2008). Why has the UK government ${ }^{1}$ consistently promoted prison building as a cornerstone of penal reform? At a time of far-reaching austerity why was HM Treasury prepared to authorise such an ambitious programme of capital investment? How have prison building programmes shaped, and in turn been shaped by, the long-term developmental trajectory of penal policy in England and Wales? These questions invite greater scrutiny. Building upon the theoretical work of Loader and Sparks (2004) this paper offers a 'historical sociology' of prison building programmes that will trace the evolution of this little understood public policy concern. It will situate prison building within a broader penal policy framework and consider how past political choices have shaped the prison system we experience today. It presents a detailed historical excavation of the five major phases of prison building in post-war England and Wales, before turning to the key sites of policy contestation which have come to define the lifecycle of prison building programmes in this jurisdiction.

\section{Situating Prison Building Programmes}

Prison building programmes defy simple analysis. Like many spheres of penal policy, they are Janus-faced, at once embodying an administrative response to sentencing practice, and an inherently political project intended to (re)shape the scale, scope and reach of the carceral state 
(Barker and Miller 2018). As has been documented elsewhere (Newburn 2007), the prison population in England and Wales increased significantly in the second half of the twentieth century, with considerable growth reported in the mid-to-late 1990s. Incarceration rates must be understood as one pillar of a far broader penal apparatus (Garland 2001), however they are suggestive of a deeper realignment in the political economy of crime. The broad contours of this shift are well documented within the literature which draws attention to the gradual breakdown of the rehabilitative ideal (Allen 1981) and the emergence of a highly politicised 'penal populism' which has fundamentally altered the contemporary penal landscape (Pratt 2007). Over time this punitive turn has driven an incarceration rate in excess of those reported in other Western European jurisdictions with profound implications for a prison estate that has rarely been sufficient to accommodate a growing, and demographically complex, cohort of prisoners (Cavadino et al 2013).

While assessments of estate capacity remain inherently problematic (see King et al 1980: 114-121) the Certified Normal Accommodation (CNA) metric can be used to construct a partial historical account of the Prison Service's official estimate of how many prisoners can be held in 'decent and safe accommodation'. CNA estimates reveal that the prison estate in England and Wales grew from 25,354 in 1960 to 77,220 in 2015 when the latest phase of prison building was announced (See Figure 1). While representing significant real-terms growth in estate capacity, the CNA benchmark has consistently fallen short of the overall prison population resulting in widespread prison overcrowding which continues to the present day (HMPPS 2018: 4). As Morgan and Liebling have argued, the effects of this operational shortfall have not been felt uniformly across the prison estate but concentrated within local prisons which continue to perform a critical gatekeeping function. At once receiving prisoners from, and delivering them to court, and assessing those sentenced to longer custodial sentences prior to their onward transfer into adult training prisons (2007: 1116). While steps have been taken 
to modernise the local prison estate, Victorian-era prisons remain the workhorses of the British penal system, holding prisoners in conditions that have frequently been criticised by HM Inspectorate of Prisons (HMIP 2018).

Figure 1: The average prison population and 'Certified Normal accommodation' (CNA) of the prison estate in England and Wales, 1960-2015

Administration of this large and functionally segmented prison estate represents a significant cost to the taxpayer. According to its most recent Annual Report, HMPPS is responsible for 102 public sector prisons, 14 private prisons, five youth offender institutions, one immigration removal centre and three secure training centres. The service employs 46,500 staff with a total operating budget of $£ 3.7$ bn per annum (HMPPS 2018: 8). This penal assemblage is often presented as a natural administrative counterpoint to crime, but in reality, the prison system we experience today is an artefact of past political choices and like all public policy outcomes, it can be altered by government action (Rutherford 1984). Since 1945, the UK government has, with varying degrees of success, exercised control over four principal levers of penal policy which have both impeded and catalysed the growth of the prison population. First, it has exerted a combination of soft and hard influence over sentencing practice in order to alter the flow of prisoners into the custodial estate. Second, it has regulated the resettlement of prisoners through the use of 'early release' and other end of sentence mechanisms. Third, it has pursued a number of 'tactical management' practices, such as overcrowding drafts, intended to address underoccupancy within the prison estate. Fourth, it has made use of prison building and estate modernisation programmes to increase (and reconfigure) the overall capacity of the prison estate. It is this final pillar of government penal policy that provides the central focus of this article. 


\section{The Legacy of Prison Building Programmes}

It is because prison building exists in close symbiosis with these other levers of penal policy that the term has often been used imprecisely. In this article 'prison building programme' is used to describe a capital strategy that encompasses the provision of additional places within existing establishments, the conversion of camps or other accommodation to prison use, and the construction of new 'purpose built' prison establishments (TNA: HO391-452). For this reason, prison building must be distinguished from ongoing revenue commitments and related capital costs, such as repair and maintenance contracts. Contrary to the triumphant rhetoric often favoured by politicians, new prison building programmes do not result in the immediate unveiling of new prison establishments but signal rolling programmes of investment intended to deliver a specified number of 'prison starts' per annum, typically over the course of a public spending round (TNA: T353-58). It is not unusual for government to re-announce existing commitments or extend legacy programmes and this can make it difficult to identify the start and end point of a prison building programme with any degree of precision. For this reason, this article will eschew the language of discreet and time bound policy initiatives, and following Rutherford (1984), refer instead to five major 'phases' of prison building.

Owing to these conceptual difficulties, and the associated methodological challenges of gaining access to closed corners of the policy cycle, we know little about how such large investment decisions are made, by whom and for what reasons. There remains little empirical research on the arguments marshalled within spending departments to justify investment in new prison building programmes or how business cases take shape across Whitehall. Still less is known about HM Treasury as a criminal justice actor, or how it has interacted with spending departments, through the annual Public Expenditure Survey. As Jones and Newburn have argued, criminologists have tended to focus their analytical gaze upon the content or consequences of penal policy rather than its origins (2004: 59) and prison building programmes 
remain one of many 'black boxes' within contemporary criminal justice. There has been considerable criminological discussion of the prison as potent symbol of state power (Foucault 1977), prison planning and architecture (Fairweather and McConville 2000; Jewkes and Moran 2017), and sociological accounts of mass incarceration (Schoenfeld 2018). In contrast, we know far less about how this key site of penal-policymaking was interpreted, and contested by, policy actors who were themselves embedded within deep institutional structures of power and meaning. As a result, prison building has often been defined in opposition to abolitionist policies (Mathiesen 2015) or the natural corollary of 'upstream' political choices (Howard League 1974).

In reality, this is one aspect of a far broader vista. Across time and place, prison building has given physical expression to a wide spectrum of policy concerns with expenditure decisions justified on the basis of such varied objectives as improved training and rehabilitation facilities, enhanced security and the alleviation of prison overcrowding (Rutherford 1984). The competition for control over finite resources is one of the defining tasks of government and the flow of money through central government departments can reveal a great deal about their organisational structure and the complex dynamics of power, prestige and routine that underpin collective decision-making (Rock 1995: 1). In this way, prison building programmes connect the past, present and possible futures of penal policy, and offer a unique vantage point from which to view the administration of punishment at a time when the State (Barker and Miller 2018), penal policy-making (Annison 2018) and policy-transfer (Jones and Newburn 2004) have emerged as key sites of criminological inquiry.

\section{Prison Building in Comparative Historical Perspective}

Drawing upon the theoretical work of Loader and Sparks (2004) this section moves on to develop a historical sociology of prison building programmes. Informed by detailed archival 
research and exploratory interviews with policy-makers, it begins to shine a light on aspects of the policy-making cycle that are often hidden from public scrutiny. A detailed methodological note is beyond the scope of this paper (see Guiney 2018), but as Loader and Sparks have argued, a grounded 'historical sociology' of crime can help to foment a 'more quizzical historical sensibility that is attuned to the trajectories of competing practices, ideologies and ideas and the legacy particular signal events and conflicts bequeath us today' (2004: 14). Thinking about policy change in this way has significant implications for research design. Moving beyond 'analytical snapshots' to view penal policy-making in 'moving pictures' demands a far greater degree of historical contextualization than is typical within the social sciences (Pierson 2004: 1). This epistemological trade-off requires a more constructive dialogue between theory and empirical particulars, which in turn will often force historical criminologists deeper into case study. So it is here. Between 1959 and 2015, the UK government embarked upon five major phases of prison building in England and Wales which are discussed below chronologically.

Constructing the 'rehabilitative ideal', c1959

Following 1945, no purpose-built prison establishments were opened in England and Wales for more than fifteen years (Peterson 1960: 308). In part, this reflected the availability of surplus military facilities, but it also speaks to the economic realities of post-war Britain. As Sir Phillip Allen, a Home Office Permanent Secretary, would later note, 'for obvious reasons it was difficult to get a satisfactory prison building programme going after the war, since we could hardly argue that prisons should take priority over schools, hospitals and roads' (TNA: HO391-457). This attitude began to shift as modernisation of the nation's ageing infrastructure moved up the political agenda (Windlesham 1993). In 1957 the new Home Secretary, R.A. Butler, inherited a number of capital works from his predecessors. Construction was almost 
complete at Everthorpe, Yorkshire and Treasury authority had been granted to build a new adult prison in Hindley, Greater Manchester and a secure psychiatric prison at Grendon Hall, Buckinghamshire (TNA: T221-856). These projects, alongside several smaller borstal facilities, were in various stages of development and Butler worked closely with his officials to re-position prison building as the centrepiece of a wide-ranging penal reform programme. In the landmark White Paper Penal Practice in a Changing Society the Home Office concluded that prison building was now a 'pre-requisite of progress' (1959: 21) and the Prison Commission, a forerunner to the Prison Service, was authorised to embark upon a major capital programme consisting of thirteen new adult prisons, including a large open prison at Ford, West Sussex (TNA: T221-856). This wide-ranging investment was intended to deliver 8,000 prison places over a ten-year period at a projected cost of $£ 621 \mathrm{~m}$ (2017 prices) (TNA: T221863).

Penal Practice in a Changing Society is now widely seen as a high watermark of the rehabilitative ideal as an expression of official policy (Windlesham 1993) and the prison building programme became the capital expression of this ethos. The White Paper drew heavily from the Gladstone Committee in its determination to transform a Victorian prison estate founded upon notions of control and penance to a 'modern' system of treatment and rehabilitation (TNA: T227-1883). Critically, this broad disposition was shared by many in the political class. Reflecting upon the proposed scheme the Chief Secretary to the Treasury remarked that 'the need to replace out-of-date prisons and to get rid of the present overcrowding of prisons represents one of the major social needs of our time...' (TNA: T221:856). It was in this context that an inter-departmental 'development group' was established in 1958 and chaired by Arthur Peterson, then Deputy Chairman of the Prison Commission, with a broad term of reference to examine both the design and cost effectiveness of new penal establishments. Preparatory work was initially hampered by a shortage of in- 
house real estate expertise however, the development group did propose design innovations in cell block planning, security and training facilities that were later incorporated into the plans for HMP Blundeston (Peterson 1960: 312). Construction quickly followed at sites in Hindley, Ashford, Risley and Styal (TNA: T221-859) however. working arrangements between the Prison Commission, Ministry of Works and local planning authorities proved unwieldy. Officials clashed repeatedly on matters of prison design, and construction was often subject to significant delay and budget creep (see Guiney forthcoming). Many establishments from this period have now been decommissioned, and it is perhaps ironic that a prison building programme expected to modernise the existing Victorian custodial estate, would itself present serious operational challenges to a future generation of prison administrators (Fairweather and McConville 2000).

Building for the future, c1969.

Judged as a capital strategy, Penal Practice in a Changing Society fell short of the lofty ideals espoused by the Home Office. On average, it took more than seven years for new establishments to become fully operational, during which time the demands placed upon the penal system had changed beyond all recognition (Home Office 1969). The late 1960s witnessed a 'prison boom' of unparalleled urgency and this general picture was further complicated by the Mountbatten Report which recommended a radical overhaul of security arrangements in British prisons (Home Office 1966). While crime was still largely insulated from party politics, prison escapes were a breakthrough electoral issue and the 1970 Conservative Party manifesto committed the party to 'restore the prison building programme, taking special care to provide secure detention for the most dangerous criminals'.

This political backdrop helped create a policy window for new investment, but the eventual shape of the proposed building programme owed as much to internal machinations 
within Whitehall as it did to reported operational pressures. In the early 1970s the Home Office Statistical Unit published a series of troubling prison population projections indicating that the average prison population would rise to over 60,000 by 1980 (TNA: PCOM14/18). In response, the Exchequer had authorised a $£ 1.6 b n$ (2017 prices) investment to undertake an unprecedented prison-building programme intended to deliver 3,000 new prison places per year and bring the CNA of the prison estate up to 57,500 by 1979 . As the Permanent Secretary would later note, this investment was not simply about penal expansion but a more fundamental repurposing of a prison estate that was still struggling to come to terms with the new security landscape postMountbatten,

On the adult side we propose to concentrate on providing new training prisons. Our immediate need is more Category $\mathrm{C}$ training prisons, for both short and mediumterm prisoners. By about 1975 however, we shall need to start construction work on a new series of training prisons for Category B prisoners. Our purpose in building more training prisons is to provide places for as many as possible of the sentenced prisoners who at present have to remain in overcrowded local prisons. (TNA: HO 391: 452)

Once again, Home Office governance and project management resources began to crystallise around prison building. A Prison Building Committee, chaired by the Director General, was established in November 1969 and this was supported by a new division of the Prison Department (P1) with oversight of all new prison building (TNA: HO391-375). Within a few years, however, the formative prison building programme began to unravel as the economic prospects for the UK deteriorated. Prison outturn data contradicted the departments' own statistical forecasts and it was clear this variance had affected the Treasury's 'attitude to our proposals for new schemes, in particular their willingness to give early approval to standard design briefs for new establishments' (TNA: PCOM14/ 18). Over time this issue became more pronounced and following a pivotal meeting with the Chief Secretary in 1973 the prison 
building programme was halved from a projected 17,000 additional places over a five-year period. Flagship projects were mothballed in Lincolnshire, Surrey, Kent, and Cambridgeshire (TNA: HO291/1509). A confidential Treasury memorandum would later reveal that, 'politically it would be impossible to cut Education or Health expenditure' (TNA: T353-58) and the 'May Cuts' announced by the Chancellor in 1974 fell heavily on defence, home affairs and local authority spending. Following a loan agreement with the International Monetary Fund (IMF) in 1976, further austerity measures were imposed across Whitehall with significant implications for the trajectory of penal policy in the years that followed (Windlesham 1993).

Ending the 'bogus numbers game', c1981.

It would take more than a decade for a prison building programme of comparable scale and ambition to be realised. The 1979 Conservative Party Manifesto declared that 'we will spend more on fighting crime, while we economize elsewhere', and prison building was a primary beneficiary of this commitment. Far from an exception to the monetarist policies pursued by the early-Thatcher government, extant Treasury records indicate that investment in law and order was a key pillar of that project,

The Government is committed, as central to all its policies, to reducing the volume of public expenditure, to reducing the size of the public sector and, on any policy account, to reducing the size of the Public Sector Borrowing Requirement... At the same time the Government is committed to giving priority to law and order in general terms. Within the total mix of expenditures on law and order most emphasis has so far gone on police and probation, with less for prisons. (TNA: T375-257)

Momentum for prison reform had gathered pace since the May Committee inquiry on the United Kingdom Prison Service (Home Office 1979) and this coupling of the government's macro-economic and penal policy aspirations was critical in moving prison building up the policy agenda. Established in 1978 following widespread industrial action by the Prison 
Officers Association (POA), the May Committee cast doubt on the potential of non-custodial measures to deliver a serious reduction in the prison population, concluding that, 'the penal estate has become so run down that rebuilding and refurbishing is inevitable' (Home Office 1979: 152). The Home Office seized upon this recommendation but securing investment from an institutionally sceptical HM Treasury would prove altogether more difficult. Historically, the Prison Department had attempted to assess its capital requirements in terms of population forecasts, matched with CNA estimates. In reality, these projections had proved an unreliable basis for decision-making. In a highly influential memorandum circulated to senior managers in December 1980, Duncan Buttery, Head of P1 Division, encouraged the Home Office to abandon this 'bogus numbers game' and accept that without dramatic and sustained decreases in the prison population a major construction programme was unavoidable (TNA: T484/249). The failure of the 1970s programme still loomed large in the collective consciousness and the thrust of this argument was accepted by Ministers. In March 1981, the Home Secretary, William Whitelaw, set out his vision for management of the penal system to Cabinet in the following terms,

I regard the prisons crisis as the most serious challenge which we face in the law and order field. There is a real risk of a breakdown. I intend to meet it principally in three ways, following the May Committee report. First, we must maximise the efficiency with which we use our existing resources... Second, we must cut our excessive demands on the prisons from unnecessary or excessive custodial sentences... The third arm of this strategy is to carry forward a relatively modest but vital programme of capital works... (TNA: T357/257)

Following this exchange, the Home Office embarked upon a major building programme including new local prisons in Milton Keynes, High Down and Belmarsh. Further capital was released in 1986 as a burgeoning remand population began to spill into police custody suites (Le Vay 2015) and the Home Office regathered after a 'summer of discontent' which saw serious disturbances at HMP Northeye and Erlestoke Youth Custody Centre. These events 
threatened to undermine the government's law and order reputation (Zander 1989) and the Treasury was quick to authorise further construction, including adult prisons in Ashford and Doncaster (TNA: T492-375).

The new normal, c1992.

The basic assumptions underpinning Whitelaw's approach to management of the penal system endured for much of the 1980s. The White Paper Crime, Justice and Protecting the Public declared that, used improperly, imprisonment can be 'an expensive way of making bad people worse' (Home Office 1990: 6). This was followed by disturbances at HMP Strangways and the resulting Woolf Report would prompt a radical overhaul of the working practices, culture and organisation of the prison service (Home Office 1991). This settled worldview began to collapse in the mid-1990s as the Major government grappled with mass unemployment associated with the 'Lawson boom', the destabilizing effects of 'Black Wednesday' and the growing political threat from the Labour Party which had moved in a more punitive direction under Shadow Home Secretary Tony Blair (Downes and Morgan 2007: 258). David Faulkner has described the populist backlash against the Criminal Justice Act 1991 as, 'probably the most sudden and the most radical which has ever taken place in this area of public policy' (quoted in Gibson et al. 1994: 84), and while the Woolf reforms continued to exert considerable influence over prison managers the rhetoric of 'prison works' fundamentally re-shaped that operating environment.

After a period of relative stability, the prison population began to rise dramatically, and this provoked an immediate administrative response within government. In a memorandum to the Home Secretary dated July 1993, and subsequently leaked to The Guardian newspaper, the Director General of the Prison Service, Derek Lewis, set out a range of options for the future development of the prison system. This included short-term contingency measures including 
temporary accommodation at closed military sites, the acquisition of two prison hulks and an application to HM Treasury for an additional $£ 684$ m (2017 prices) to resource an emergency building programme (The Guardian 1993). The department also began to explore the potential of private sector investment to upgrade the prison estate whilst simultaneously reducing the governments immediate public sector borrowing requirements (Le Vay 2015). Hitherto, the Home Office had been guarded in its dealings with the private sector (Jones and Newburn 2004), but the landmark 1992 Autumn Statement introduced a new Public Finance Initiative (PFI) intended to increase private sector involvement in the provision of public services, including prison management. Thereafter events moved quickly. On the 2 September 1993, Michael Howard, confirmed that henceforth the design, construction, management and financing (DCMF) of all prisons would be contracted out to the private sector. This policy was fleshed out in greater detail at the 1993 Conservative Party Conference and it was later revealed that six new prisons would be built under the DCMF strategy, including vanguard sites at Fazakerley and Bridgend.

While providing some temporary respite, additional capital investment did not definitively address the issue of prison overcrowding. As the prison population continued to rise, the emergency accommodation plans alluded to by Derek Train quickly became business as usual for the Home Office, with significant implications for the architecture and design ethos of new prison establishments (Jewkes and Moran 2017). As Elaine Bailey, a former Head of the Home Office Construction Unit has noted, an emergency prison building initiative was introduced in 1996 with a mandate to pursue 'economies of scale' and other administratively expedient measures such as bringing mothballed accommodation back into use and the purchase of a prison 'hulk', HMP Weare, that would be moored in Portland Harbour from 1997 to 2006 (2000: 73-84). 
'Building out inefficiencies', c2001.

During its thirteen years in office New Labour would construct more than 27,000 new prison places (Grimwood 2016: 17), a figure in excess of the CNA of the entire prison estate in 1961. This was achieved through two administrative mechanisms. First, a standing 'core capacity programme' was introduced to deliver a rolling programme of estate modernisation based upon cell reclamation, the expansion of existing prison establishments and the construction of new prisons in high demand areas. These increases in estate capacity represented a considerable, and ongoing cost to the taxpayer. As the Ministry of Justice (MOJ) would later note in a memorandum to the Justice Committee,

The capital construction cost of the core capacity programme $(12,500$ places $)$ is approximately $£ 2$ billion. To date, $£ 1.3$ billion has been spent on construction and we expect spend to remain within budget. Annual running costs of the places delivered as part of the core capacity programme are forecast to be $£ 484 \mathrm{~m}$ once all the projects are delivered... (MOJ 2009: 17)

This investment significantly altered the capacity and configuration of the prison estate. New public prisons were opened at HMP Kennet, HMP Littlehey and HMP Isis, and while the Labour government did row back on Michael Howard's DCMF strategy, new private prisons were opened at HMP Thameside and HMP Oakwood (Grimwood 2016: 17). Despite unparalleled investment, and repeated changes to the operation of parole, Home Detention Curfew (HDC) and an emergency 'End of Custody Licence (ECL) scheme, prison overcrowding continued to worsen in the early part of the twenty-first century. In June 2007, Lord Falconer announced that the Exchequer had authorised additional capital investment to 'help accommodate the current pressures' (Hansard 19 June 2007). This investment became a key focus for the 'Carter Review' of prisons, established by the Prime Minister in December 2007 (Carter 2007). In echoes of the earlier May Committee, Lord Carter cast doubt on the potential of non-custodial measures to significantly reduce the prison population and expressed 
concern that without further increases in estate capacity the MOJ were unlikely to accommodate the projected growth in the prison population in the short, medium or long-term (Carter 2007: 2).

These recommendations were accepted by the UK government. Initially the MOJ announced its intention to construct three "Titan" prisons, each housing 2,500 inmates, a proposal described as a 'gigantic mistake' by the Prison Reform Trust (2008). However, following an adverse public consultation, this was eventually replaced by a 'new prisons programme' intended to deliver 7,500 prison places across five medium-sized jails. The capital costs of the 'new prisons programme' were estimated at $£ 1.2 \mathrm{bn}$ with planning permission submitted in Runwell, Essex and further acquisitions anticipated in areas of 'strategic need' including Wrexham, North Wales (Grimwood 2016: 17). Critically, the 'new buildings programme' was designed to sit alongside the existing Core Capacity Programme and support the government to achieve its aim of increasing the capacity of the prison estate to 96,000 places by 2014 (MOJ 2009). In time this may come to be seen as the high-water mark of prison construction in England and Wales. Following the 2008 global financial crisis, the Coalition Agreement committed the UK government to a sweeping programme of deficit reduction with significant implications for prison administration. In this context, the MOJ took steps to consolidate the existing prison estate resulting in several prison closures, including HMP Lancaster Castle, and the repurposing of establishments such as HMP Morton Hall, into an Immigration Removal Centre (Grimwood 2015: 20).

\section{Discussion}

The case studies presented in this paper offer a unique insight into the developmental trajectory of penal policy in post-war England and Wales. It is clear that the 'punitive turn' experienced by many western jurisdictions has fundamentally altered the policy levers that the UK 
government has been willing to exercise in managing the prison population, and in the longterm this readjustment has made it more likely that a political response encompassing prison building will prevail (Hough et al 2008; Hedderman 2008). As the 'penal arms race' gathered pace in the mid-1990s, prison building moved from the margins to the mainstream of penal policy-making occupying a contradictory position as both a potent symbol of law and order politics and the toxic corollary of 'runaway prison expansion' (Prison Reform Trust 2008). Moreover, this analysis takes us further in our understanding of how prison building programmes mediate between the normative claims of penal policy-makers and the pragmatism of prison administrators who must confront the world as it is. While prison debate has tended to focus on the overall capacity of the prison system (Burke 2008), it is clear from extant archival records that prison building has played an altogether more complex role in the expansion, modernisation and reconfiguration of the prison estate - functionally, geographically and architecturally (see for example, Jewkes and Moran 2017). Further research is required to unpick this complex dynamic fully, but the analysis set out in this paper equips us with the empirical tools to interrogate this general picture in greater detail than has previously been possible. In this respect, a historical sociology of prison building programmes draws attention to three inter-locking dimensions of penal policy contestation.

\section{Problem framing}

Since 1945, the cornerstone of British penal administration has been a commitment to an 'open door' policy of accommodating those sentenced to custody by the courts (Zander 1989). Over time this policy posture-reflecting deep-rooted assumptions about the liberal-democratic state and the projection of governing competence-has exerted a strong influence over penal policymaking in England and Wales, helping to frame penal questions in ways that have discounted 
some reform pathways whilst making others more likely. Consider, for example, the following extract from a meeting between senior Home Office and HM Treasury officials,

The Treasury raised the question of the effects of changes in criminal justice policy on the size of the prison population. [Home Office Officials] felt that legislation or executive intervention to constrain judicial discretion was an extremely delicate area and many of the suggestions for sharply and permanently reducing the prison population by such means which had been floated in the past were still likely to be politically unacceptable. (TNA: T375-256)

By separating out supply and demand-side questions in this way, many possible sites of prison policy contestation were defined out as externalities or empirical facts, and therefore placed beyond the scope of legitimate departmental action. Stripped of its inherent political character, it was widely assumed that the prison population inclined towards a natural equilibrium and was therefore self-correcting in the medium-to-long term. As one senior official would note, 'statisticians are sceptical about the potential for policy changes to bring down the prison population. In the past... there has been a saw tooth effect as policy changes have temporarily reduced the growth...' (TNA: T484-10). For policy-makers inculcated within the tradition of British penal pragmatism, the central purpose of penal policy was to promote continuity, and measures to reduce the prison population were therefore treated as short-term palliatives to be activated during periods of acute operational stress. Since the prison population could not be controlled entirely from within this policy framework, prison building retained an important residual role: to control exogenous prison growth in an orderly and planned fashion, and leverage in additional investment from the Exchequer during periods of budget expansion. The key point being that one supply side measures such as deflationary sentencing policies were ruled out as 'politically unattractive, periodic prison building programmes were required to maintain the government's institutional commitment to the 'open door' policy. It was only in the mid-1990s as penal expansion became an explicit aim of penal policy that this pragmatic 
policy equilibrium began to breakdown and sustained capital investment was necessary to meet unprecedented growth in demand for prison places (Hedderman 2008; Burke 2008).

\section{Collective decision-making}

Within this analysis the 'future' emerges as a profoundly political concept and a focal point for penal policy-making. In part, this orientation towards the future was reinforced by the annual rhythm of the Public Expenditure Survey (PES), which explicitly linked the allocation of resources to future requirements (Rock 1995). But it also speaks directly to the enduring political appeal of monument building and the desire to project one's political values into an uncertain future. Entrepreneurial policy-makers have always found creative ways to unlock new investment streams through the Whitehall bidding process, but what makes the history of prison building so interesting is how policy-makers have frequently reverted to a largely apolitical and technocratic position with regards to prison building, seeking to define the future with reference to the past and immediate present (TNA: PCOM14/18). In this respect they were often confronted by a broad constellation of interest groups which have occupied a more overtly normative position orientated towards the world 'as it ought to be' and the possibility of radical policy change. Nowhere was this clearer than in the use of prison population forecasts to determine future capital requirements. As King et al have argued, population forecasts are often presented as an objective and impartial presentation of the facts when, in reality, they embody a series of deeply political assumptions about the world;

Existing trends reflect past and present priorities and choices. Extrapolating those trends is not to portray, in a non-political fashion, a pattern of behaviour over which we have no control. Rather it portrays the continuation of past and present political choices. If those extrapolations become the basis of future resource allocation then, to a greater or lesser extent the perpetuation of these choices becomes a selffulfilling prophecy. (King et al 1980: 48) 
Population forecasting can never be a substitute for political choice but framing the debate in this way has been effective in shifting prison debate away from a broader battle of ideas to narrow technocratic questions of interpretation that radically alter the balance of power between information consumers and information providers. Knowledge is power, and this applied whether dealing with citizens, penal reform organisations or powerful institutions such as HM Treasury. While the Exchequer is often presented as all powerful in its dealings with spending departments, and instinctively opposed to large capital investments, the reality is far more nuanced. Its power is typically that of reviewer rather than author, and with the notable exception of periods of enforced austerity in the 1970s and early 2010s, the Treasury has frequently authorised new investment. Significantly, this often occurred at the last possible moment within the expenditure cycle, undermining long-term strategic planning within the penal system, a process Le Vay has characterised as akin to 'laying the track just in front of the engine' (2015: 19).

\section{Implementation and the 'geography of administration'}

Finally, this historical sociology of prison building programmes draws attention to the complex 'geography of administration' (Hennessey 1989) that underpins the British machinery of government. This article has explored the delicate negotiations that took place within Whitehall as new prison building programmes took shape, but this was only a formative step in the policymaking cycle (TNA: HO391-457). Once capital investment was authorised, the UK Government were entirely dependent upon a complex chain of service providers to discharge the responsibilities of site acquisition, design, planning and construction. In this respect, the way ideas 'travelled' as they cascaded down through these dense policy networks has exerted a powerful legacy over the contemporary penal landscape. 
We know, for example, that central government departments have often struggled with a well-documented 'implementation gap' and over time, the private sector would come to play a central role in bridging the divide between prison building policy, planning and construction. At the start of the period in question responsibility for prison building was divided between the Ministry of Works who were responsible for 'the building of all new purpose-built establishments on virgin sites' and the Home Office Directorate of Works who took a lead on 'new prison places by the extension of existing establishments' (TNA: HO391/305). In 1972, this responsibility was transferred to the Property Service Agency (PSA), a non-departmental public body, sponsored by the Department of the Environment, who would come to play a prominent role in promulgating the 'new public management' that emerged under the Thatcher Government. As Michael Heseltine, the Secretary of State for the Environment would note in one such exchange with the Home Secretary,

\begin{abstract}
As you know, my policy for PSA is that it should draw increasingly on the resources of the private sector in carrying out its work. This means that the bulk of the new prison building programme will be undertaken by consultants, with PSA managing the overall programme and liaising with consultants on standards and specifications, cost control and monitoring progress. (TNA: T375-257)
\end{abstract}

This ethos laid the material and ideological groundwork for later developments (Le Vay 2015). Private sector involvement in the administration of criminal justice has rightly been a topic of significant criminological interest, both as a matter of principle and as a potent signal of broader political economic shifts associated with the emergence of neo-liberalism (Jones and Newburn 2004, Le Vay 2015). However, this analysis indicates that the growing role of the private sector was, initially at least, a response to the complex geography of administration within Whitehall at a time when administrators were under significant pressure to reduce costs and lead-in times associated with large capital projects. 


\section{Conclusion}

Once again, prison building stands at a crossroads in England and Wales (Justice Committee 2019). While the UK Government has recently renewed its commitment to estate modernisation with the announcement of a new 1,680-place Category $\mathrm{C}$ prison in Wellingborough at an expected cost of $£ 253 \mathrm{~m}$, it remains to be seen whether the wider programme of capital investment announced by the Chancellor and Justice Secretary in 2015 will ever be fully realised. In this respect, the current prison building programme is emblematic of penal policy-making in an era of inertia where the UK government has consistently struggled to square the circle of significant reductions in public expenditure, a stubbornly high prison population and a restrictive political consensus that continues to circumscribe the appropriate aims and techniques of penal policy (Downes and Morgan 2007). At a time of unprecedented uncertainty in British politics it remains to be seen how penal policy-makers will negotiate the competing claims of penal populism and a rejuvenated penal pragmatism, or what this will mean for the demands placed upon the prison estate in future. History can be an unreliable guide to action, however the analysis set out in this paper strongly suggests that prison administrators will continue to oscillate between normative and pragmatic postures towards prison building. If additional capital expenditure is forthcoming it is likely to be shaped by the competition for control of finite resources, deeply held assumptions about liberalism and the limits of the state, and the enduring 'geography of administration' that defines the British machinery of government.

\section{Notes}


${ }^{1}$ The term 'UK Government', is used here to refer collectively to the various Departments of State with responsibility for new prison building in England and Wales since 1945. This includes the Home Office, Ministry of Works, HM Treasury and Ministry of Justice.

\section{References}

\section{Primary Source Material}

The National Archives (TNA): HO291-1926. Home Office: Penal reform: penal policy development; suggestions by the Home Secretary; prison population forecasts

. HO291-1509. Home Office: Prison population forecasts.

. HO391-375. Home Office: Joint Prison Building Steering Committee.

. HO391-452. Prisons Board: paper on future prison places and population; submission to Ministers.

. HO391-305. Annual Conference 1970; statement on prison building programme.

. HO391-457. Home Office: Prison Building Programme.

. PCOM14-18. Prison Commission: Prisons Board Minutes and Papers.

. T221-856. Treasury: Prisons. Building of new prisons in England and Wales. 
. T221-859. Treasury: Prisons. Building programme.

. T221-862. Treasury: Prisons. Papers leading up to White Paper on penal reform.

. T227-1883. Treasury: Prison building programme: England and Wales; general papers.

. T353-58. Treasury: Public Expenditure Survey 1973: contingency plans for reductions in 1973-1975.

. T375-257. Treasury: Prison building programme over the next ten years.

. T484-249. Treasury: Prison building programme: general policy.

. T492-375. Treasury: Public Expenditure Survey (PES) 1986: review of prison issues.

Secondary Source Material

Allen, F. (1981) The Decline of the Rehabilitative Ideal: Penal Policy and Social Purpose. New Haven: Yale University Press.

Annison, H. (2018), 'The policymakers' dilemma: change, continuity and enduring rationalities of English penal policy'. British Journal of Criminology, 58/5: 1066-1086 
Bailey, E. (2000), 'Building for growth' in L. Fairweather, L and S. McConville, eds., Prison Architecture: Policy, Design, and Experience. Oxford: Architectural Press.

Barker, V., and Miller, L.L (2018), 'Introduction to the special issue on the state of the State'. Theoretical Criminology 21(4): 417-421.

Burke, L. (2008), 'Can we build our way out of the prison crisis?' Probation Journal, 55(1): $5-8$.

Carter, L. (2007), 'Securing the Future: Proposals for the Efficient and Sustainable Use of Custody in England and Wales. Cabinet Office.

Cavadino, M., Dignan, J., and Mair, G. (2013), 'The Penal System: An Introduction'. 5th edn. London: Sage.

Conservative Party. (1970), 'A Better Tomorrow: The Conservative Party General Election Manifesto 1970'. London: Conservative Party

. (1979), '1979 Conservative Party General Election Manifesto’. London: Conservative Party.

Downes, D., and Morgan, R. (2007), 'No turning back: The politics of law and order into the millennium' in M. Maguire, R., Morgan., and R, Reiner., eds., The Oxford Handbook of Criminology, 4th Edition. Oxford: Oxford University Press. 
Fairweather, L., and McConville, S., eds. (2000), 'Prison Architecture: Policy, Design, and Experience’. Oxford: Architectural Press.

Foucault, M. (1977), 'Discipline and Punish: The Birth of the Prison'. New York: Pantheon.

Garland, D. (2001), 'The Culture of Control: Crime and Social Order in Contemporary Society'. Oxford: Oxford University Press.

Gibson, B. et al. (1994), 'The Youth Court: One Year Onwards'. Winchester: Waterside Press.

Grimwood, G.G. (2016), 'Building prisons in England and Wales: the bigger, the better?' House of Commons Library.

. (2018), 'Excavating the Archive: Reflections on a Historical Criminology of Government, Penal Policy and Criminal Justice Change'. Criminology \& Criminal Justice. https://doi.org/10.1177/1748895818810333

Guiney, T. (forthcoming), Constructing the 'rehabilitative ideal': Revisiting the legacy of the 1959 prison building programme. Prison Service Journal

Hedderman, C. (2008), 'Building on Sand: Why Expanding the Prison Estate is not the Way to 'Secure the Future', Briefing 7. London: Centre for Crime and Justice Studies.

Hennessy, P. (1989), 'Whitehall'. London: Secker \& Warburg. 
Home Office. (1959), 'Penal Practice in a Changing Society: Aspects of Future Development (England and Wales)'. London: HMSO

. (1966), 'Report of the Inquiry into Prison Escapers and Security (Mountbatten Report)'. London: HMSO.

. (1969), 'People in Prison'. London: HMSO.

. (1979), 'Report of the Committee of Inquiry into the United Kingdom Prison Services (May Committee)'. London: HMSO.

. (1990), 'Crime, Justice and Protecting the Public: The Government's Proposals for Legislation'. London: HMSO.

. (1991), 'Prison Disturbances April 1990; Report of an Inquiry by the Rt. Hon. Lord Justice Woolf and his Honour Judge Stephen Tumim'. London: HMSO.

HMIP. (2018), 'HM Chief Inspector of Prisons for England and Wales Annual Report 2017 18'. London: HMSO.

HMPPS. (2018), 'HM Prison and Probation Service Annual Report and Accounts 2017-18'. London: HMSO.

Hough, M., Allen, R., and Solomon, E., eds. (2008), 'Tackling Prison Overcrowding: Build 
more prisons? Sentence fewer offenders?' Bristol: Policy Press.

Howard League. (1974), 'Ill-founded premises: The logic of penal policy and the prison building programme'. London: Howard League for Penal Reform

Jewkes, Y., and Moran, D. (2017), 'Prison Architecture and Design: perspectives from criminology and carceral geography', in A. Liebling., S. Maruna and L. McCara., eds, The Oxford Handbook of Criminology (6th edition). Oxford: Oxford University Press.

Jones, T., and Newburn, T. (2004), 'Comparative criminal justice policy-making in the United States and the United Kingdom: the case of private prisons'. British Journal of Criminology, 45(1): 58-80.

Justice Committee. (2019) 'Prison population 2022: planning for the future. Sixteenth Report of Session 2017-19’. London: HMSO.

King, R.D., Morgan, R., Martin, J.P and Thomas, J.E. (1980), 'The Future of the Prison System'. London: Gower.

Le Vay, J. (2015), 'Competition for Prisons: Public or private?' Bristol: Policy Press.

. (2017), 'Assessment for the Prison Reform Trust of the Financial Outlook for HM Prison Service, 2017-25'. London: Prison Reform Trust 
Loader, I. and Sparks, R. (2004), 'For an Historical Sociology of Crime Policy in England and Wales since 1968'. Critical Review of International Social and Political Philosophy, 7(2): 5-32.

Mathiesen, T. (2015), 'The Politics of Abolition Revisited'. London: Routledge.

Ministry of Justice. (2010), 'Government response to the Justice Committee's Report:

Cutting crime: the case for justice reinvestment'. MOJ.

. (2015), 'Prison building revolution announced by Chancellor and Justice Secretary'. 9

November 2015.

Morgan, R., and Liebling, A. (2007), 'Imprisonment: An Expanding Scene', in M. Maguire,

R. Morgan and R. Reiner., eds., The Oxford Handbook of Criminology (4th edition). Oxford: Oxford University Press.

Newburn, T. (2007), “'Tough on Crime”: Penal Policy in England and Wales' in M. Tonry, ed., Crime, Punishment and Politics in Comparative Perspective. Volume 36 of Crime and Justice: A Review of Research. Chicago: University of Chicago Press.

Peterson, A.W. (1960), 'The Prison Building programme'. British Journal of Criminology 1(4): 307-316.

Pierson, P. (2004), 'Politics in Time'. Princeton: Princeton University Press. 
Pratt, J. (2007), 'Penal Populism'. London: Routledge.

Prime Minister's Office. (2016), 'Prison reform: Prime Minister's speech'. 8 February 2016

Prison Reform Trust. (2008), 'Titan prisons: a gigantic mistake’. London: Prison Reform Trust.

Rock, P. (1995), ‘The Opening Stages of Criminal Justice Policy Making'. British Journal of Criminology, 35(1): 1-16.

Rutherford, A. (1984), 'Deeper into the Quagmire” Observations on the Latest Prison Building Programme’. Howard Journal of Criminal Justice, 23: 129-37.

Schoenfeld, H. (2018), 'Building the Prison State: Race and the Politics of Mass Incarceration'. Chicago: Chicago University Press.

The Guardian. (1993), 'Prison ships planned for two ports'. The Guardian, 19 July 1993.

. (2017), 'Closures of ageing jails on hold for five years as prison numbers soar'. The Guardian, 12 October 2017.

Windlesham, L. (1993), 'Responses to Crime. Volume 2: Penal Policy in the Making'. Oxford: Clarendon Press. 
Zander, M. (1989), 'A Matter of Justice: Legal System in Ferment'. Oxford: Oxford University Press.

Figure 1: The average prison population and 'Certified Normal accommodation' (CNA) of the prison estate in England and Wales, 1960-2015

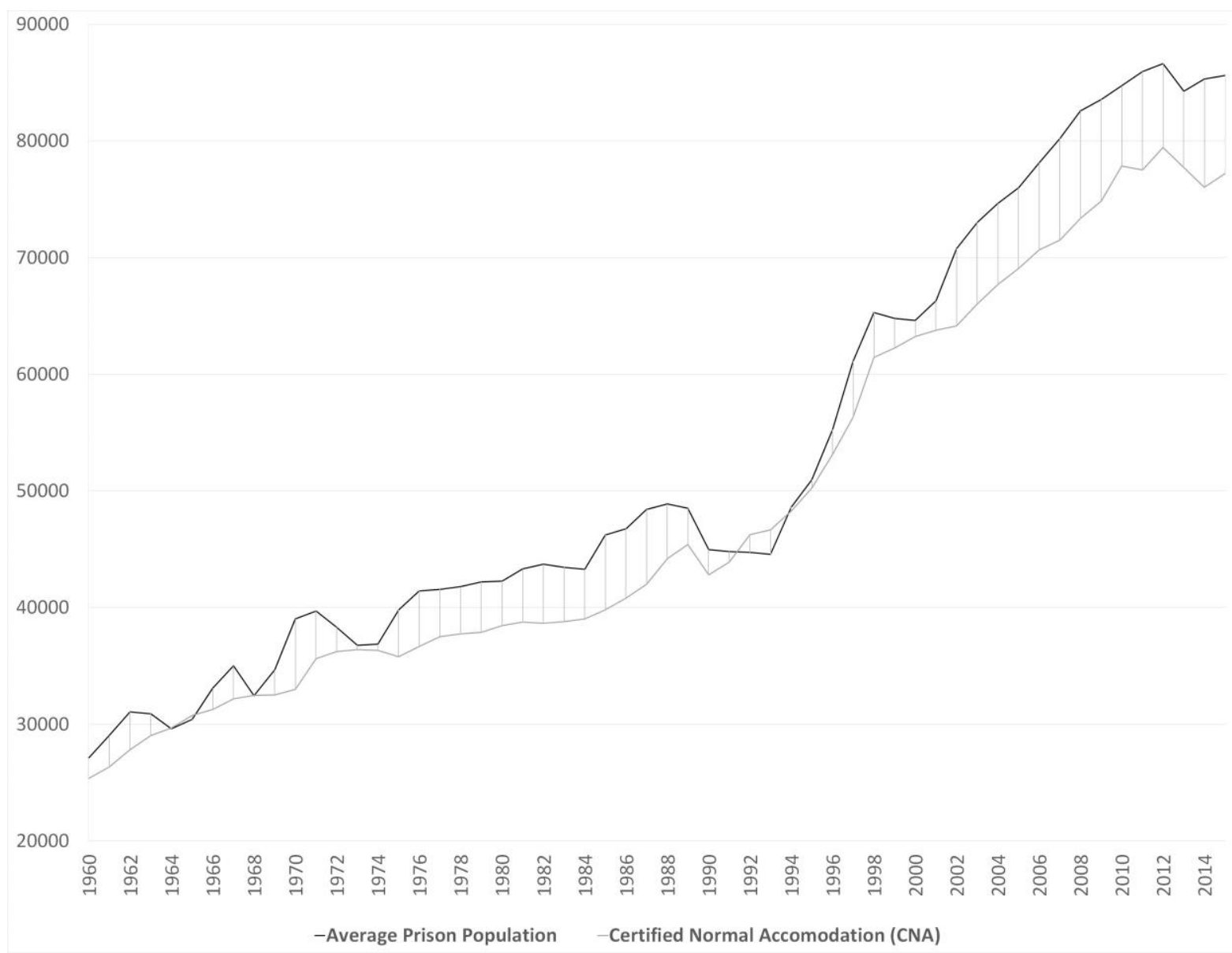

